\title{
脳梗塞に関する実験的研究
}

\author{
フリーズフラクチャーレプリカ (FFR)法による毛細血管透過性の超微形態 \\ 学的検討
}

井上優

\section{Experimental Cerebral Infarction in the Dog}

Ultrastructural Study of Capillary Permeability by Freeze-fracture Replica

Masaru INOUE

Department of Neurosurgery, Nagasaki University, Nagasaki

\begin{abstract}
Underlying mechanisms which lead to brain edema following ischemic insults have been subjects of much debate. In this study, experimental cerebral infarction was produced in dogs by injecting one or two silicone rubber cylinders through the cervical internal carotid artery. Twenty-four hours after embolization, animals were killed and morphometrical analyses in the capillary endothelial cell membranes in the cortex were done by freeze-fracture replica in addition to conventional ultra-thin section using the transmission electron microscope.

In ultra-thin sections of capillary endothelium in the ischemic cerebral cortex, surface infolding and increase in number of pinocytotic vesicles were recognized, but no findings of opening of tight junction were ascertained.

In freeze-fracture replicas of capillary endothelium of both normal and ischemic cerebral cortex, tight junction was presented as the network of ridges composed of about $100 \AA$ particles on the protoplasmic face $(\mathrm{PF})$ and grooves on the extracellular face $(\mathrm{EF})$. In the ischemic cortex, arrangement of strands of these protein particles was not changed. In replica preparations, too, no definite findings of opening junction were certificated. Pinocytotic vesicles were seen as invaginations on the $\mathrm{PF}$ and as protrusions on the EF. In the ischemic cortex, the average number per square $\mu \mathrm{m}$ was increased. On the luminal front, it reached to 22.0 (on the PF) and 29.5 (on the EF) as compared to 7.2 and 9.0 in the normal cortex, respectively. The size of vesicles was also enlarged; $4,990.7 \pm$ $798 \mathrm{~nm}^{2}$ (on the PF) and $4,762.8 \pm 878 \mathrm{~nm}^{2}$ (on the EF) as compared to $3,567.7 \pm 570 \mathrm{~nm}^{2}$ and $3,404.5 \pm 573 \mathrm{~nm}^{2}$ in the normal cortex, respectively.

These results indicate that transcellular transport by pinocytotic vesicles has an important role in increase of capillary permeability observed in an ischemic model.
\end{abstract}

Key words: cerebral infarction, freeze-fracture replica, capillary, brain edema, electron microscope 


\section{Iはじめに}

急性期脳梗塞に伴亏脳浮腫の発現機序については, 組織

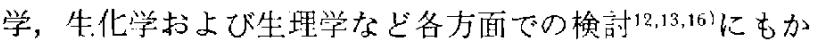
かわらず，な㧍不明な点が多い，特に動物奏験において は，種や週柃による血管楧築の特異性8,17,28，梗塞モデル 作製法の迲い10.19)，虚血岾問や梗塞部領域の程度などによ り得られた成縝に大きな相違が認められる。また浮朠発現 の基盤を成す毛紐血管透過性の変動に関する研究は，色素 や horseradish peroxidase などのトレーサーを使ったも の2,20iが主であった。

私は今回，シリコン山柱注入によるモデル犬゙25.31：を用 い，梗塞24時問後の人脳皮質虚血巣における毛細血管队披 練胞をフリーズフラクチャーレプリカ(以下 FFR)法によ り検討し, 従来の超薄切片では解明が困難であった pinocytotic vesicle や tight junction な上゙の形態学的变化を上り 詳練に観察し，血管透過性の亢進や脳浮腫発生の機预につ いて考察を行った。

\section{II 実験方法}

\section{1. 脳梗塞モデル犬の作製}

体重 $10 \mathrm{~kg}$ 㷙後の雑㮔成犬を用い，ケタラール筋注(5 $\mathrm{mg} / \mathrm{kg})$ ，ネンブタール静注 $(25 \mathrm{mg} / \mathrm{kg})$ 麻酔下に気管内搟 管を行い，調節呼吸下に頸部傍正中切開を加元，一倒内頸
動脈より $1 \times 8 \mathrm{~mm}$ のシリコン円柆 2 個在注入して脳梗塞 巣孝作製し，24時閏後に脱血，ただちに脳を取り出した。

\section{2.レプリカ膜の作製}

視交灵のレベルで ectosylvian gyrus より $1 \times 1 \mathrm{~cm} の$ 皮 筫老切り出し，約10分問 $3 \%$ glutaraldehyde，1\% paraformaldehyde, $0.1 \mathrm{M}$ cacodylate buffer $\left(\mathrm{pH} 7.4,0^{\circ} \mathrm{C}\right)$ で固定传, 奏体湿微鏡下に $1 \times 1 \times 3 \mathrm{~mm}$ の四角柱切片とし，さらに 同一固定液で24時間浸瀆固定索行った。切片在 cacodylate bufferで一晚洗鿟し，米絬防止のため同緩衝液を含む $30 \%$ glycerol で約 $1 \sim 2$ 時間脱水後, 液体窒素で泠却した freon 22 で涷結し, $-130^{\circ} \mathrm{C}, 1 \times 10^{-6}$ torr の条件下で $\mathrm{EE}-$ FED-B 凍結割断装置(日本電子，東京)在用いて凍結割断 を行った。ついで割断面に platinum-paradium, carbon $の$ 真空蒸着在行い，ブリーチ液( sodium hypochlorite)で約 1 時間組織を溶解し，蒸留水で洗㴪後レプリ力暯を作製し， JEM-100 B 型電子顕微鏡 (日本電子, 東京)で観察した.

\section{3. 超薄切片の作製}

四的柱切片の一部は1\%osmium tetroxide で後固定を行 い, ethanol 系列で脱水後 Epon 812に包埋して超薄切片を 作製し, uranyl acetate, lead citrate で二重染色在行以観察 した.

なお，刘照として正常犬でも同様の $2 つ の$ 標本を作製 し, 観察を行った.

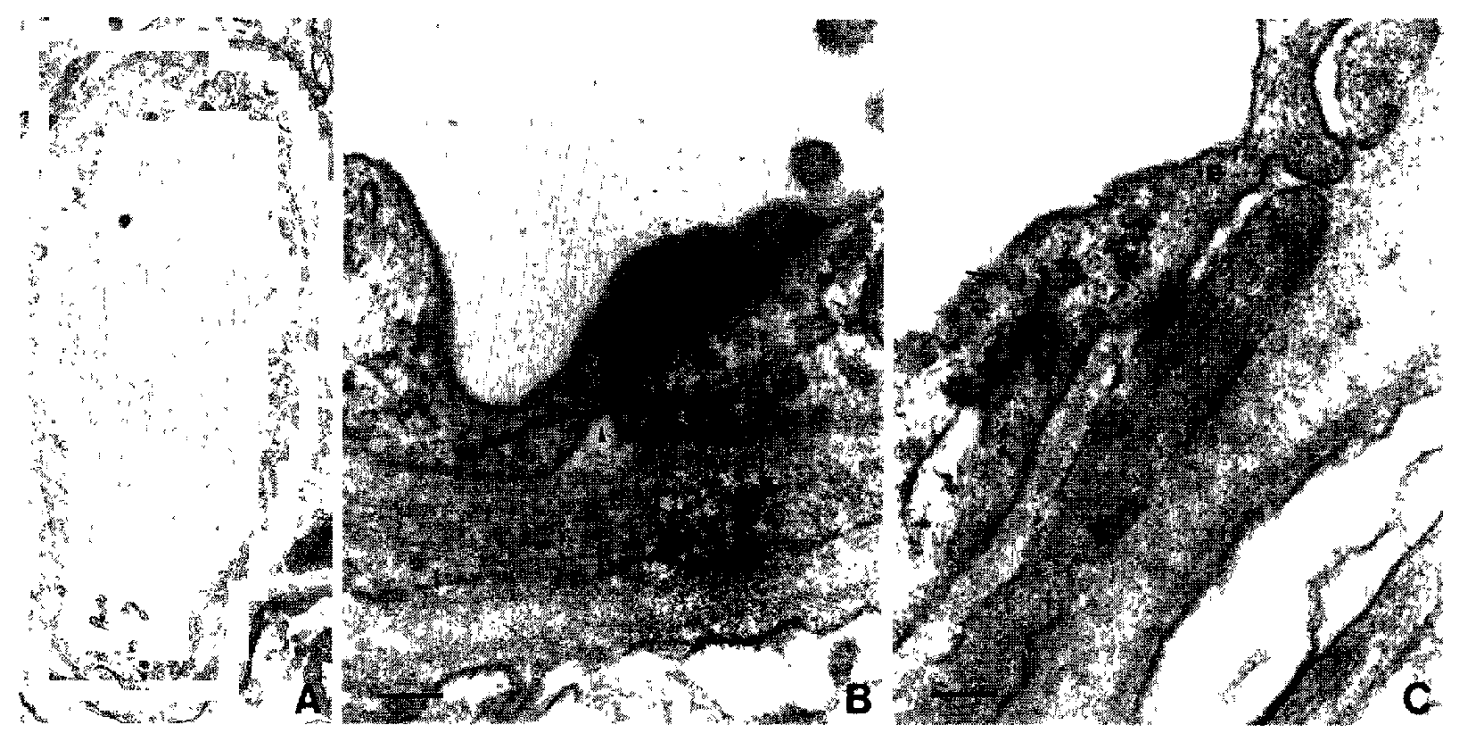

Fig. 1 A Electron micrograph of a capllary located in modcrate edematous cortex at 24 hours after embolization. A capillary shows surface infolding and pericapillary fluid collection. $\times 21,000$, Bar $=1 \mu \mathrm{m} \quad$ B Higher magnification of the same case. The endothehal junction is almost closed by an extensive zonula occludente (arrows), but the basal portion opens to the basal lamina (arrowhead). $\times 100,000, \mathrm{Bar}=0.2 \mu \mathrm{m}$. C. Higher magnification of the same case The wall of a capillary endothelial cell (e) is thinned, in which the formation of pinocytotic vesicles are observed (arrozes) $\quad \times 100,000, \mathrm{Bar}=02 \mu \mathrm{m}$ 


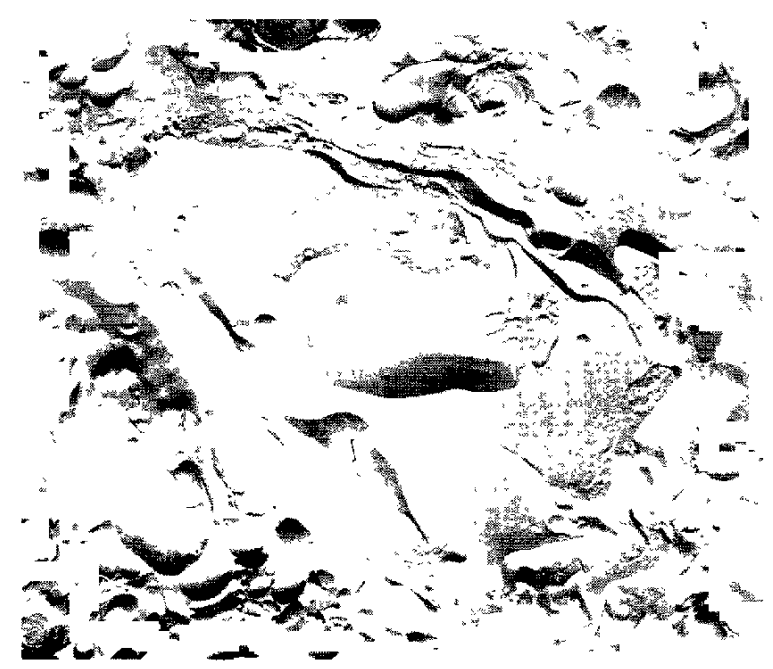

Fig 2 Electron micrograph of freeze-fracture replica of a capillary endothelium in the normal cerebral cortex Pinocytotic vesicles are seen not only on the protoplasmic face ( $\mathrm{PF}$ ) on the luminal front side, but also on the PF in the abluminal side (arnw) There is a erythrocyte (c) in the capllary lumen Direction of shadowing is shown by an arrowhead in an open corcle $\times 21,000, \mathrm{Bar}=1 \mu \mathrm{m}$

\section{III 結果}

シリコン円柱塞择街在施行した雑種成犬80頭のうち45頭 で組織学的に脳梗韭在羿め，さらにそのうち大兴半球大梗
塞巣，すなわち入脳基底核を含んだ皮質哊質の梗塞巣が認 められたものは25䫓であった。これら25䪽で超薄切片扔上 びFFR 慓本を作製した。

\section{1. 迢薄切片所見}

中大脳動脈阙寨24日寺间後の大脸皮質部の電顕像では，毛 細血管内皮細胞に marginal infoldingの倾向が認められた. また basal lamina が膨化し，㹡大した perivascular space には浮腫液が賍留し，neuropil も膨化していたが赤血球の 血管外漏出は認加られず，いわゆる vasogenic edema の像 を示していた（Fig，1A)，毛細组管内皮細胞閒の tight junctionの開大注怣好られない(Fig. 1B)が，毛細血管の内腔 側，細胞質内，そして基底膜側のいずれに沶いても内皮細 胞の pinocytotic vesicle が增加していた。しかし channel 形成 ${ }^{18)}$ はみられなかった(Fig. 1C)。

\section{FFR 所見}

正常犬の皮質毛細血管：Fig. 2 は正常犬の大脳皮質毛細 血管レプリカ像であり，さらに強昖大寸ると protoplasmic face (PF) に caveola が (Fig. 3A), extracellular face (EF)に注 pitが贸められた(Fig. 3B)。つまり，FFRにお いて pinocytotic vesicle 注 PF で阥凹, EFで隆起として観 察され，直径泣約 $65 \mathrm{~nm}$ であった。 また, tight junction 沈 相接する内皮細胞の抢の抢のの形筫膜に線状もしくは網日 状に配列した膜內粒了. (intramembranous particle: IMP) と して傕察され，PFでは ridge, EFでは grooveな像を示し た. Fig. 4 は正常犬の tight junctionの1例を示し, PF で

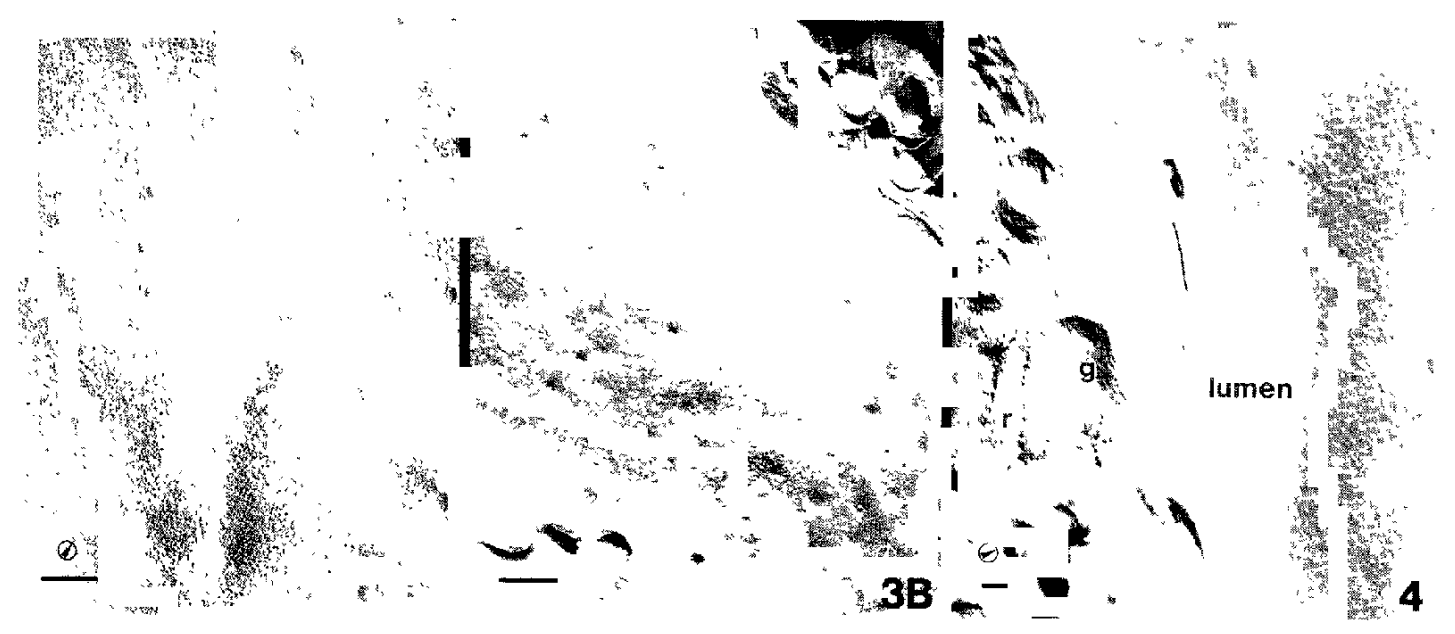

Fig. 3 Higher magnification of the same case as in Fig 2. A Pinocytotic vesicles are observed as invaginations on the PF B: Pinocytotic vesicles are seen as protrusions on the extracellular face (EF) Direction of shadowing is shown by an arrowhead in an open circle. $\times 63,000, \mathrm{Bar}=03 \mu \mathrm{m}$

Fig 4 Freeze-fracture replica of a capilary endothelium in the normal cortex composed of about $100 \AA$ particles on the PF and grooves $(\mathrm{g})$ on the EF open circle $\quad \times 86,000, \mathrm{Bar}=02 \mu \mathrm{m}$

Tight junctions are observed as a network of ridges ( $r$ ) Direction of shadowing is shown by an arrowhead in an 

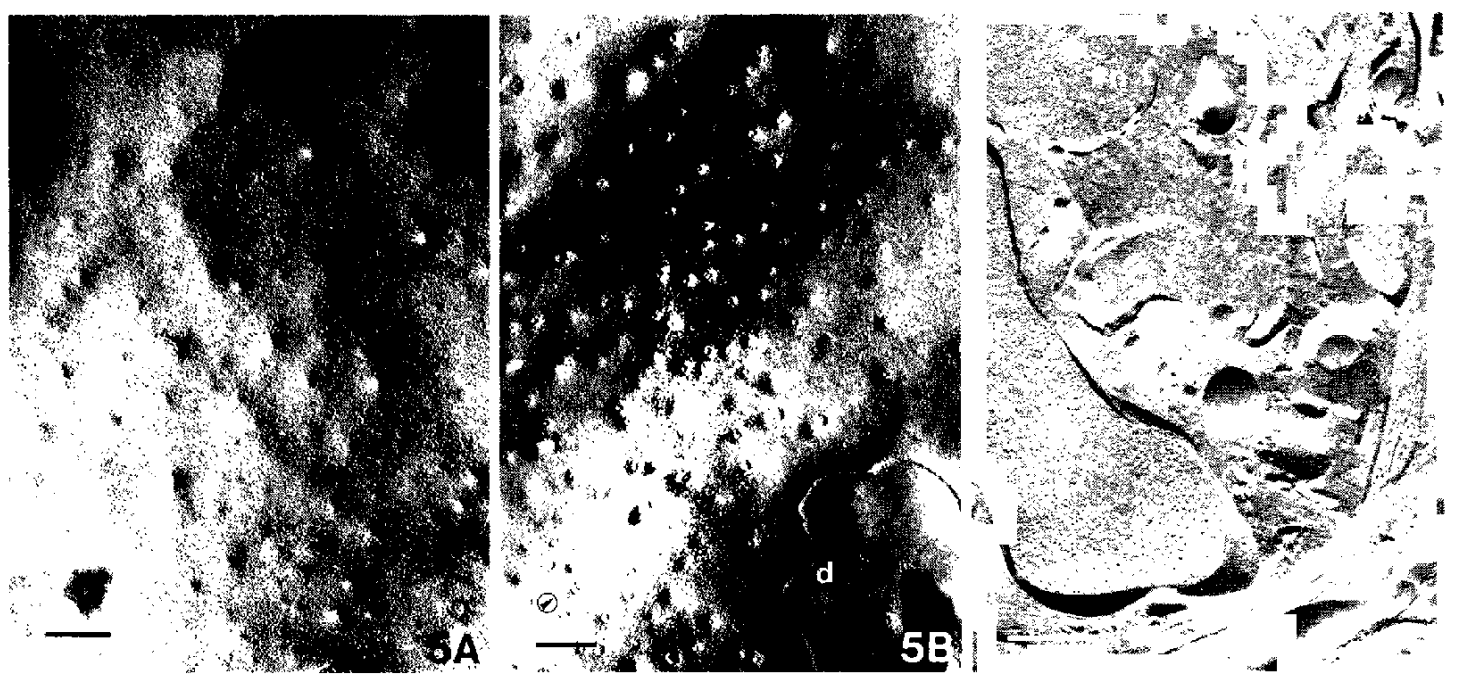

Fig. 5 A: Freeze-fracture replica of a capillary endothelium in the ischemic cortex at 24 hours after embolization. Pinocytotic vesicles on the $\mathrm{PF}$ increased in number, and are enlarged in size. B: EF of the same case. Increased and large pinocytotic vesicles are observed and desmosome $(d)$ is seen toward the right lowcr corner of photograph. Direction of shadowing is shown by an arrowhead in an open circle. $\times 63,000, \mathrm{Bar}=0.3 \mu \mathrm{m}$.

Fig. 6 Freeze-fracture replica of a capillary endothelium in the ischemic cortex. Tight junction on the PF has 6 strands and arrangement of particles are not irregular (arrows). Vascular lumen (1), endothelial cell (e), nucleus $(\mathbf{n})$. Direction of shadowing is shown by an arrowhead in an open circle. $\times 54,000, \mathrm{Bar}=0.5 \mu \mathrm{m}$.
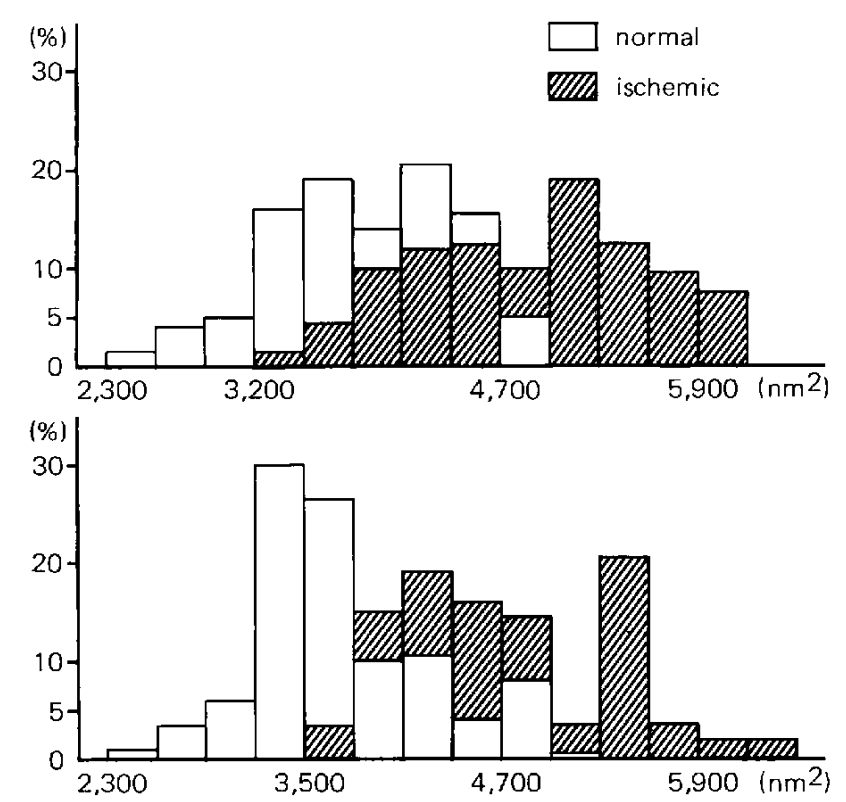

Fig. 7 Histograms of the size of pinocytotic vesicles on the $\mathrm{PF}$ (upper) and EF (lower) in normal versus ischemic capillary endothelium plasma membrane of the cerebral cortex.

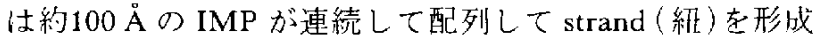
し，さらにこれら 5 条の strand が網目状の network t形 成しており，一力 EFでは groove となっていた。

梗塞24時間後の皮椞毛細血管：24㭙間後の毛細血管内皮 細胞においては, pinocytotic vesicleの数の増加のほかに直 径の增大がみられ，PFでは約85 nm (Fig. 5A), EFでは的 $90 \mathrm{~nm}$ (Fig. 5B)であった。また,これら pinocytotic vesicle は, vesicle 周井のIMPが辺縁に沿って集族しているも のとIMPが付随していないものとの 2 種類に分けるこ上 ができた。 一方 tight junction は，やはり100 ̊のIMPが $\mathrm{PF}$ で ridge, EF で groove な像を呈しており，正常犬のそ れと比較しIMPの配列にやや不連続が認められたが， strandの数には大きな変化はみられなかった(Fig. 6).

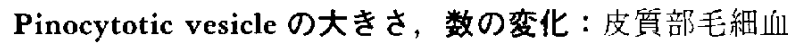
管内皮細胞膜面( 部30力所) 撮影した写真在倍率約70,000 倍とし，画像解析システム(MYPAD-A3 Logitec Digitizer Model K-510，関東電子，東京) を用い，毛細血管内空側 のPF，EFに㧍ける pinocytotic vesicle の面積を計測した (Fig. 7)，正常犬(10頭，15力所)においてはPFで3,567.7 $\pm 570 \mathrm{~nm}^{2}, \mathrm{EF} て ゙ 3,404.5 \pm 573 \mathrm{~nm}^{2}$ ，昼畦はそれぞれ恢场

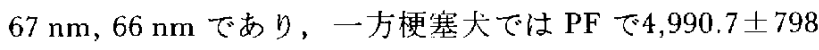
$\mathrm{nm}^{2}, \mathrm{EF}$ で4,762.8土878 $\mathrm{nm}^{2}$, 直径はそれぞれ $80 \mathrm{~nm}, 78$ $\mathrm{nm}$ となり，正常犬に比し約1.2倍大きくなっていた，さら に，単位面皘当りの pinocytotic vesicle $の$ 数は，正常犬の 
$\mathrm{PF}$ で平均7.2/ $/ \mathrm{m}^{2}, \mathrm{EF}$ で9.0/ $/ \mathrm{m}^{2}$ であったのに対し梗塞犬 では $\mathrm{PF} て ゙ 22.0 / \mu \mathrm{m}^{2}, \mathrm{EF}$ で $29.5 / \mu \mathrm{m}^{2}$ であり，㤦塞犬で約 3 倍に增加していた。

\section{IV 考 察}

生休膜性内外 2 枚の燐脂質層から構成され，それぞれの 疎水面を膜の内側に，親水面を膜の外側に向忖ており，こ の燐脂質層の中に蛋白粒子が浮遊しているとされている。 FFR 法に扔いては分子間結合力がもっとも弱い眯水部分, つまり膜の中心部で離開が生じるため, 膜队構造を広い範 囲で二次元的に観察することができる。また，IMP 海割 断されたどちらかの配に牫るかあるいは真中で制ら机る゙ が，膜の内側面を細胞の外から眺为た場合が PF，逆注細 胞内から膜の外側面をみた場合が EF であり，通常 IMP はPFに多く認められる ためには, shadowing の向が写真の下から七へ向かうよ らにして見なければならない。

1953年，Palade 法経細胞輸送( transcellular transport)機 構の概念として“飲み込み小胞(pinocytotic vesicle)”の存 在を提唱した。その後多くの研究4.5)がなされ，垷在では 高分子、たとえば血漿蛋白の輸送に特に重要な役割を果す 上言われている3,23)。また，脳のいろいるな抦態(外傷，

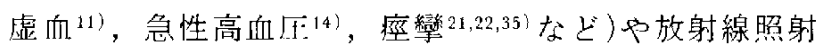
後29;などで pinocytotic vesicleの増加がみられ，特に脳梗 塞急性期の脸浮腫発生に伴 5 pinocytotic vesicle の増加は,

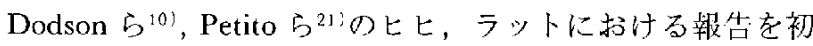
め諾家のほぼ一致した見解と思玑る。しかしながらこれ らの報告は寸べて超薄切片の観察によるものであり，FFR 法による検討報告はみあたらない，FFR 法では割断面が 紐胞膜内部孛接線方向に通過し，ために細胞膜は通常の超 薄切片のように“線”ではなく“面”として観察されるた め，pinocytotic vesicle の娭討には非常に有用な方法7,26,30; である。令回の実験沈いても，pinocytotic vesiclc の増加 は超薄切片でも諗められたが，その止確な大きさや数の分 析注電顕の解像力からみても不十分上思われた。

今回の24時間梗塞犬に扔いて，vesicle 注正常犬に比し数 で約 3 倍，大きさでも約1.2倍に增加および执大しており， 血管の透過性が充進していることを強く示唆していた，し かし，あくまでも形態面からの推定に留まっている。ま た, Wagner ら ${ }^{34}$ は pinocytotic vesicle は二方向性(bidirectional)の移動を示し，内腔側掞よび基底膜側のいずれの側 においても飲み込みと放出が同時に進行していると述べて いるが，観察されたそれぞれの vesicle がいずれの動き在 しているのかの鑑別もできなかった。今回の岀験結果で は, 周辺部のIMP の分布状態は IMP が集合しているも
のと乏しいものとに分かれていたが，前若が取り边みを示 寸像，後者が放出，開口の過程を示す像に相当するのかる しれない，今後の詳細な锘討を必要とするが，IMPが pinocytotic vesicleの形成，機能になんらかの役割を果して いることは十分予想される。

一，血管内皮細胞䦗隚は超薄切片での観察による上， 相接する内皮細胞の形質膜が按着しているいわゆる tight junction 之䄪 $20 \AA$ の間隙存有する gap junction 上から战。 ている，虚血性脍障㕩においては，内皮細胞の tight junctionは開かないとする報告が多い.FFR 法では脳毛細血 管の tight junction は約100 $の$ 蛋白粒于が連続して配列 した 5〜 6条の strandが絆日形成して扔り ${ }^{1.6 .27 .33 ! ， 今 ~}$ 回の実娩条件下に括いては junction を構成する strand 数は正常犬のそ扎之大美なく，また粒子配列の不連続性む 認好なかった ${ }^{15}$. ただし，Van Deurs ${ }^{32}$ は閉鎖带を構成す る蛋白粒子の荷需状態によりイオン透過性に差がみられる としており，単に粒子配列の連続件のみから tight junctionの非開存を論定することはできず，今後さらに検討を 荌する問題上㤁わ扎る。

現在，各種トレーサーを用いた娭討らのほかに FFR 法 にオートラジオグラフィーを併用する試みが行われてお $\eta^{24)}$, 今後形態学的にも分子レベルでの研究がさらに進む ものと期待される。

\section{$\mathrm{V}$ まとめ}

1.シリコン栓子による中大脳動脈閉塞モデル犬を用 い，虚血部皮質毛細血管の透過性について通常の超薄切片 法に加えフリーズフラクチャーレプリカ(FFR)法による電 顕的検討走行った。

2. 電影卜, FFRでは虚血部皮質毛細牦管において pinocytotic vesicle $の$ 数は正常犬に比し約 3 倍と有意に增加 していた。一力，毛細血管内皮細胞間の tight junction は FFR では利100Åの膜队粠子で形成された strandから成 る網目状の配列が認められ，正常犬に比し变化はなかっ た。

3. 以上の所見上り，急性期脳梗寒に伴う脳浮腫発垷の 一因として，毛細血管内皮細胞における pinocytotic vesicle による透過性亢進の関与が強く示唆された。一方, tight junctionの变化は強くないと思われた。

4. FFR 江毛細遄管内皮細胞膜の超微形態学的研究に 有用な子段と考えられた。

稿を終えるにあたり，御指導・御校閲を賜りました長崎大学脸

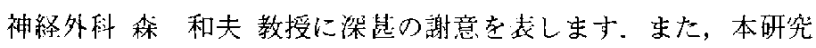
に直接の御指導党頂きました柴田尚武助教授，ならびに其同研 


\section{究者諸氏に深く感謝致します。}

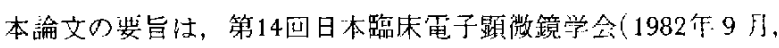
東京)扔上び第8 8 回口本脳卒中学会総会(1983年6月，仙台)に㧍 いて発表した。

\section{文献}

1) Branton D: Fracture faces of frozen membranes. Proc Nat Acad Sci USA 55: 1048-1056, 1966

2) Brightman MW, Hori M, Rapoport SI, Reese 'I'S, Westergaard E: Osmotic opening of tight junctions in cerebral endothelium. J Comp Neural 152: 317-326, 1973

3) Bruns RR, Palade GE: Studies on blood capillaries. 1. General organization of blood capillaries in muscle. J Cell Biol 37; 244-276, 1968

4) Gastejón OJ: Electron microscopic study of capillary wall in human cerebral edema. J Neuropathol Exp Neurol 39: 296-328, 1980

5) Chien S, Laufer L, Handley DA: Vesicle distribution in the arterial endothelium determined with ruthenium red as an extracellular marker. $J$ Ultrastruct Res 79: 198-206, 1982

6) Claude P, Goodenough DA: Fracture faces of zonulae occludentes from "tight" and "leaky" epithelia. J Cell Biol 58: 390400,1973

7) Connel CJ, Mercer KL: Freeze-fracture appearance of the capillary endothelium in the cerebral cortex of mouse brain. $A m J$ Anat 140: 595-599, 1974

8) Coyle $\mathbf{P}$ : Middle cerebral artery occlusion in the young rat. Siroke 13: 855-859, 1982

9) Crévecoeur M, Deltour R, Bronchart R: Quantitative freezefracture study of plasmalemma and nuclear envelope of Zea mays root cells during carly germination. $J$ Ultrastruct Res 80: 1-11, 1982

10) Dodson RF, Aoyagi M, Hartmann A, Tagashira $Y$ : Acute cerebral infarction and hypotension: An ultrastructural study. $J$ Neuropathol Exp Neurol 33: 400-407, 1974

11) Garcia JH, Conger KA, Briggs L: Brain capillaries in acute and subacute regional ischemia, in Cervós-Navarro J, Fritschka $\mathrm{E}$ (eds): Cerebral Microcirculation and Metabolism. New York, Raven, 1981, pp 83-91

12) Garcia JH, Kalino H, Kamijyo $Y$, Trump BF: Cellular events during partial cerebral ischemia. 1. Electron microscopy of feline cerebral cortex after middle-cerebral-artery occlusion. Virchows Arch [Cell Pathol] 25: 191-206, 1977

13) Garcia JH, Kamijyo Y: Cerebral infarction. Evolution of histopathological changes after acclusion of a middle cerebral artery in primates. J Neuropathol Exp Neurol 33: 408-421, 1974

14) Hedley-Whyte ET, Lorenzo AV, Hsu DW: Protein transport across cerebral vessels during metrazole-induced convulsions. $A m$ J Physiol 233: 74-85, 1977

15) 井上優, 堤 健二, 柴出阁武, 森 和夫, 并上暜久, 瀨 戸口孝夫，末松证：兴梗塞に留寸る実駼的研究一皮質毛細 血管の超微形態学的㛟討一。 日臨電影会誌 15: 793-794, 1982

16) Katzman R, Clasen R, Klatzo I, Meyer JS, Pappius HM,
Waltz AG: Report of joint committee for stroke resources. Brain edema in stroke. Stroke 8: $512-540,1977$

17) Levine S, Sohn D: Cerebral ischemia in infant and adult gerbils. Arch Path (Chicago) 87: 315-317, 1969

18) Lossinsky AS, Garcia JH, Iwanuwski L, Lightfoote WE: Ncw ultrastructural evidence for a protein transport system in endothelial cells of gerbil brains. Acta Neuropathol (Berl) 47: 105-110, 1979

19) Molinari GF, Laurent JP: A classification of experimental models of brain ischemia. Stroke 7: 14-17, 1976

20) Nagy Z, Mathieson G, Hüttner I: Blood-brain barrier opening to horseradish peroxidase in acute arterial hypertension. Acta Neuropathol (Berl) 48: 45-53, 1979

21) Petito CK, Pulsinelli WA, Jacobson G, Plum F: Edema and vascular permeability in cerebral ischemia: Comparison between ischemic neuronal damage and infarction. I Neuropathol Exp Neurol 41: 423-436, 1982

22) Petito CK, Schaefer JA, Plum F: Ultrastructural characteristics of the brain and blood-brain barrier in experimental seizures. Brain Res 127: 251-267, 1977

23) Renkin EM: Multiple pathways of capillary permeability. Circ Res 41: 735-743, 1977

24) Schiller A, Taugner R: Combincd freeze-fracturing and autoradiography techniques: Freeze-fracture autoradiography, in Heym C, Forssmann W-G (eds): Techniques in Neuroanatomical Research. Berlin, Splingcr, 1981, pp 301-314

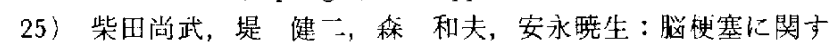
る先馱的研究（第 5 報）一梗塞巣分類について一. Neurol Med Chir (Takyo) 22: 262-266, 1982

26) Simionescu $M$, Simionescu N, Palade GE: Morphometric data on the endothelium of blood capillaries. $J$ Cell Biol 60: 128-152, 1974

27) Simionescu M, Simionescu N, Palade GE: Segmental differentiations of cell junctions in the vascular endothelium. The microvasculature. J Cell Biol 67: 863-885, 1975

28) Tamura A, Graham DI, McGulloch J, Teasdale GM: Focal cerebral ischemia in the rat. 1 . Description of technique and early neuropathological consequences following middle cerebral artery occlusion. Journal of Cerebral Blood Flow and Metabolism 1: 53-60, 1981

29) Tani E, Kochi N: Pathology of blood-brain barrier and glia. Advances in Neurological Sciences 27: 140-153, 1983

30) Tani E, Yamagata S, Ito Y: Freeze-fracture of capillary endothelium in rat brain. Cell Tissue Res 176: 157-165, 1977

31）堤 健二, 井上 優, 柴田尚武, 箖 和夫：実験的脳梗塞 一終末部および境界部における微小血管の超微形態学的变 化一，日臨電顕会誌 15:791-792, 1982

32) Van Deurs B: Vesicular transport of horseradish peroxidase from brain to blood in segments of the cerebral microvasculature in adult mice. Brain Res 124: 1-8, 1977

33) Wade JB, Karnovsky MJ: The structure of the zonula occludens. A single fibril model based on freeze-fracture. $J$ Cell Biol 
60: $168-180,1974$

34) Wagner HJ, Pilgrim C, Brandl J: Penetration and removal of horseradish peroxidase injected into the cerebrospinal fluid. Role of cerebral perivascular spaces, endothelium, and microglia. Acta Neuropathol (Berl) 27: 299-315, 1974

35) Westergaard E, Hertz MM, Bolwig TG: Increased permeability to horseradish peroxidase across cerebral vessels, evoked by elec- trically induced seizures in the rat. Acta Neuropathol (Berl) 41: 7380, 1978

[別刷請求先: $\mathbf{T} 852$ 長㥓市圾本町 $7-1$, 長崎大学脳神释外科, 井上優] 